Aleksandar Trifunović

Univerzitet u Beogradu

Filološki fakultet

aleksandartrifunovic3@gmail.com

\title{
CANKAR I JUGOSLAVIJA
}

Ideja o stvaranju zajedničke države Južnih Slovena zamisao je koja je tokom XIX veka i u prvoj deceniji XX bila vodilja mnogih političara, ali su se za tu ideju zalagali i naučnici i književnici. Godina u kojoj se obeležava stogodišnjica smrti Ivana Cankara je ujedno i stogodišnjica ostvarenja ideje, za koju se i sam pisac zalagao. Ovaj rad se bavi Ivanom Cankarem političarem i povlačenjem paralela između njegovih ideja, izloženih u eseju „Slovenci i Jugosloveni“ i onoga što se zaista dogodilo nakon prologašenja zajedničke države, kao i odzivom javnosti na ovo predavanje.

Ključne reči: Ivan Cankar, Jugoslavija, kraljevina, republika

Pesnik, prozaista, satiričar i dramski pisac, Ivan Cankar predstavlja, s pesnikom Otonom Župančičem, vrh takozvane ,slovenačke moderne" (Vidmar 1956:511). O njemu su pretežno pisali kao o književniku, dok je opisivanje njegovog političkog delovanja ostalo tek na razumevanju predavanja Kako sam postao socijalista i na kandidaturi na listi Socijaldemokratske stranke ${ }^{62}$ (Pavlič 2015: 10). Koliko je Ivana Cankara pogodio neuspeh na izborima ostaje nepoznanica, ali u većini svojih radova izražava neslaganja s tadašnjom politom. Kritičari Ivana Cankara su bili zastupnici različitih stranaka, pre svega klerikalne i liberalne, a njegove drame su uglavnom nailazile na negativan odziv.

${ }^{62}$ Godine 1907. je Ivan Cankar bio kandidat za poslanika u Beču na listi Socijaldemokratske stranke, ali nije bio izabran. Ipak, svoj politički život je nastavio u vidu predavanja i rasprava, među kojima su: Slovenački narod i slovenačka kultura, Lepa naša domovino, Slovenci i Jugosloveni, Očišćenje i podmladivanje (Cankar 1966: 73-91, 97-101, 150.157, 162-170). 


\section{Jugoslovensko pitanje}

Tokom devetnaestog veka, a naročito nakon Proleća naroda 1848. godine i nakon stvaranja dualne, Austro-ugarske monarhije, slovenski narodi, koji su živeli u njoj počinju izražavati težnje za većom stamostalnošću. Na drugoj strani, Srbija i Crna Gora uspevaju dobiti potpunu nezavisnost od Turaka na Berlinskom kongresu 1878. godine, a Bugarska autonomiju u okrviru Otomanske imperije. U XX vek južnoslovenski prostor ulazi rascepkan: slovenčaki i hrvatski krajevi se nalaze u Austro-ugarskoj monarhiji, Srbija i Crna gora su nezavisne, Bugarska to postaje 1908. godine, a Kosovo i Makedonija su još uvek pod vlašću Osmanske imperije.

Ovaj period bio je plodno tle za stvaranje ideje o ujedinjenju južnoslovenskih naroda i stvaranju zajedničke države, a javlja se kao posledica razvitka novih društevno-ekonomskih odnosa i raspadanja feudalizma (Petranović 1988: 3). Ideja je praćenja shvatanjem da su južnoslovenski narodi istorijski povezani, te da su etnički srodni. Buđenje nacionalne svesti kao jugoslovenske ideologije kao i ideja o ujedinjenu, pojavljuju se zajedno sa ujedinjenjem Italije i Nemačke, ali i kao rekacija na strah od teritorijalnog širenja drugih država na račun etničkog prostora Južnih Slovena. Ipak, sama ideja o ujedinjenju nije bila jedinstvena, već su nastajali i istovremeno ekzistirali različiti oblici ideja o jugoslovenskoj povezanosti:

- zahtev za kulturni preporod i ravnopravnost jezika;

- autonomija u stastavu sastavu Austro-ugarske;

- unija južnoslovenskih naroda

- integralno jugoslovenstvo pod okriljem Austro-ugarske

- panslavistički programi (Petranović 1988:3)

Ideja jugoslovenstva se u Hrvatskoj i Sloveniji smatrala nacionalnim preporodom, dok su na srpskoj strani postojale dve varijante: istočna - ujedinjenje Srbije i Bugarske, zapadna - stvaranje jugoslovenske nacionalne države pod vođstvom Srbije (Načertanije Ilije Garašanina iz 1844. godine ${ }^{63}$ ) (Petranović 1988:3). Pored ove, u srpskoj eliti se

\footnotetext{
${ }^{63}$ Pod uticajem poljske emigracije, protivno Austriji i Rusiji, polovinom četrdesetih godina urađen je i spoljnopolitički program Srbije - Načertanije (1844). Osnovu Načertanija formulisao je Franjo Zah, a njegovu definitivnu redakciju izvršio je Ilija Ga-
} 
razvila i ideja o balkanskoj federaciji, za koju se zalagao Svetozar Marković. Austrougarski deo južnoslovenskog prostora sve se više zalagao za stvaranje jugoslovenske jedinice u okviru Austrougarske monarhije, odnosno za stvaranje trijalističke monarhije ${ }^{64}$. Ipak, vremenom se politička misao sve više okretala ka stvaranju jugoslovenske federacije ili balkanske konfederacije. Slovenački program ujedinjene Slovenije iz 1848 godine polazio je od stvaranja jugoslovenske fedracije u kojoj bi se našle Slovenija, Hrvatska i Vojvodina (Petranović 1988:4). Za federativno unutrašnje uređenje izjašnjavaju se i Tivolska konferencija jugoslovenske scoijaldemokratije i Kruševska republika (Petranović 1988: 4).

\section{Slovenci i Jugosloveni, 12. april 1913. godine}

Prvi balkanski rat je na slovenačkim teritorijama dočekan sa oduševljenjem ${ }^{65}$. Dnevne novine koje su u to doba izlazile na slovenačkoj teritoriji (Dan, Slovenec, Slovenski narod, Straža, Zarja...) sa neskrivenim oduševljenjem prema srpskoj i bugarskoj vojsci prenose događaje sa balkanskih ratišta. U trenutku sve većeg okretanja političara ka stvaranju jedinstvene države na prostoru Južnih Slovena, Ivan Cankar u ljubljanskom Mestnom domu, u organizaciji Opšteg radničkog saveza Uzajamnost za Kranjsku održava svoje predavanje Slovenci i Jugosloveni. Između 250 slušalaca se nalazio i delegirani policijski službenik. (Rahten 2012: 184). Na samom početku, Ivan Cankar kaže:

rašanin, zamenivši Zahov izraz Južni Sloveni izrazima Srbi i „srpski narod”. Imajući u vidu rušenje Osmanskog carstva, Srbija bi, prema Garašaninovoj redakciji, trebalo u daljoj budućnosti da okupi „sve narode srpske koji je okružuju i da stvori „novu srbsku državu” i to „na starom dobrom temelju starog carstva srbskog”. (Perović 2017: 211)

${ }^{64}$ Trijalizam, ideja o udruživanju "svih južnih Slovena monarhije u državnopravno samostalan organizam pod žezlom habzburške monarhije”, kako je to definisala izjava Kranjskog državnog veća, 16. januara 1909. Trijalizam je prvenstveno zavisio od hrvatskih stavova, koji u početku nisu bili skloni povezivanju sa Slovencima (na primer, tzv. Riječka deklaracija iz oktobra 1905. godine). Slovenački političari su nastojali da uključe hrvatske, u svoje državno-pravne programe. Konačnu formu trijalistička ideja u austrijskom delu monarhije dobila je u Majskoj deklaraciji, u maju 1917, a dan pre nego što se u austrijskom delu monarhije obnovio parlamentarni život, osnovan je Jugoslovenski klub, u kome su se udružili slovenački, hrvatski i srpski poslanici iz austrijskog dela monarhije (prethodno su postojala tri kluba: Hrvatsko-slovenački, Narodni klub i Dalmatinski klub).

${ }^{65}$ Zaključak izveden nakon detaljnog istraživanja novinskih članaka 8. 10. 1912- 30. 5. 1913. listova Dan, Zarja, Slovenec i Slovenski narod (dostupno na http://www.dlib.si) 
„Izjavljujem naime, da ne govorim u ime nijedne stranke, još manje u ime celog naroda, već potpuno ponizno u svoje ime". (Cankar 1966: 150). Time je sebe hteo odaljiti od političara za koje je smatrao da govore $\mathrm{u}$ ime naroda, iako ih sam narod za to nije izabrao. Ni sam Cankar ne skriva oduševljenje srpskim i bugarskim pobedama na balaknskim ratištima tokom I balkanskog rata. Iako je naslov predavanja bio ,, Slovenci i Jugosloveni" on najveći deo svoga govora posvećuje ismejavanju austrijske spoljne politike i ministra spoljnih poslova Berhtolda:

Kad su topovi obelodanili jugoslovenski Vaskrs, i naša draga zvanična Austrija se setila jugoslovenskog problema, i počela ga rešavati na svoj način. Prvo je u Kranjskoj, Štajerskoj i Dalmaciji zatvorila nekoliko ljudi zbog veleizdaje, zatim je naredila se na bečkom Grabnu pretuče par srpskih studenata, a zatim je Srbiji i Crnoj Gori objavila rat u novinama. Na taj način je jugoslovenski problem rešen za grofa Berhtolda, a za druge, obične, ljude, je osta isto tako nerešen i komplikovan kakav je i bio. (Cankar 1966: 151)

Osim toga, stao je na stranu Srbije, smatrajući da joj pripada deo morkse obale, ne izostavljajući priliku, da iskritikuje austrijsku politiku: „Istorija nas naime uči, da je glupost austrijske diplomatije uvek bila najveći blagoslov za evropske narode" (Cankar 1966: 152). Nakon toga dotiče se i jugoslovenskog pitanja. On je napravio razliku između političkog i kulturnog jugoslovenstva: ovo drugo je smatrao nemogućim, a veoma štetnim je smatrao one, koji su se na različite načine borili za njega (Balkovec 1995-1996: 135). „Po krvi smo braća, po jeziku bar rođaci - po kulturi, koja je plod viševekovnog razdvojenog rasta, smo jedni drugima tuđini, više nego što je naš gorenjski seljak tuđ tirolskom ili gorički vinogradar fulanskom" (Cankar 1966: 154).

Ivan Cankar u ovom uverenju nije bio usamljen: prema Petru Vodopivcu ,velika većina slovenačkog naroda je o drugim Južnim Slovenima malo znala. S Hrvatima su se Slovenci sretali pretežno na granici dva naroda, a o Srbima su znali samo iz novinskih izveštaja" (Rahten 2012: 177). Budući da se zalagao za federaciju, i da je smatrao da je jugoslovenstvo samo politička zamisao, svoju najoštriju kritiku uputio je novilircima: ,, Naši, do bestvesti oduševljeni ilirci, nisu zaboravili samo na slovenačku kulturu (slovenački jezik ionako nikad nisu znali), ne samo na Trubara, Prešerna i Levstika, nego su zaboravili i sami na sebe, na svoje ime i na svoju domovinu. Pravog ilirca je sramota da stanuje u Lljubljani, u Šapcu ili bar u Varaždinu, nije" (Cankar 1966: 155-156). 
Ovo, doduše, nije jedini trenutak u kojem je iskoristio priliku da kritikuje novoilirce. U anketi naučnog i kulturnog časopisa Veda (Nauka) irazio je oštro negodovanje prema ovakvim idejama (Rahten 2012: 183). Poseban odnos prema slovenačkom jeziku Ivan Cankar je izrazio u razgovoru s Izidorom Cankarem 1911. godine, rekavši kako je „slovenačka književnost otišla veoma visoko" i ,stoji rame uz rame sa svetskom literaturom, dok Hrvati i Srbi npr. nisu svetski" (Rahten 2012:183). Sličan stav izrazio je i u svom predavanju Slovenci i Jugosloveni:

Pod austrijskim izvršiteljem, v svojoj tamnici i siromaštvu i mnogobrojnim patnjama smo uzdigli svoju kulturu toliko visoko, da je ponos i veselje. To je izraz narodne moći, koja nimalo ne zaostaje za onom moći, koja se pojavila pred Lozengradom i Kumanovom. Gledajmo da budemo u sebi zdravi, snažni i barem duhovno bogati (kad već nije drugačije), tako da ne odemo jednom ka svojoj braći, da bismo tražili milostinju, nego da im donesemo darove; ili još bolje - da sama braća dođu, da pokupe te darove, pre nego što im ih mi ponudimo (Cankar 1966: 155).

\section{Nakon predavanja}

Već sutradan, 13. 4. 1913. časopis Dan prenosi događaje u pozitivnom tonu, rekavši kako su se slušaoci ,izvrsno zabavljali“ završivši rečima: „Tako je smeo reći samo on - jer je Cankar” (Dan 1913:3). List Slovenec kritikuje Cankara rečima: „Ivan Cankar nije političar, i zbog toga njegove političke poglede ne shvatamo ozbiljno" (Slovenec 1913: 4). Oštriji je bio Slovenski narod opisujući predavanje sledećim rečima: „Dve trećine Cankarevih izjava nisu imale baš nikakve prave veze s predmetom, s temom, kratak sadržaj poslednje trećine je govorio o tome da moraju Slovenci biti oduševljeni samo političkom jugoslovenskom idejom (...) kulturnu jugoslovensku uzajamnost moramo odbiti, kako bismo (...) kad dođe do političkog združivanja Jugoslavije, činili tokolo moćan kulturni faktor, da ostalima (...) diktiramo svoju volju" (Slovenski narod 1913: 5).

Zarja (socialdemokratski list) u pozitivnom tonu prenosi događaje sa predavanja rečima: „Već s prvim rečenicama predavanja je ostvario kontakt s publikom i ova veza je do kraja predavanja ostala veoma čvrsta" (Zarja 1913: 2). Nekoliko dana kasnije isti list objavljuje i delove predavanja. Potom je uslredio i odgovor zvanične vlasti: Cankar 
biva osuđen na sedam dana zatvora, koji je odslužio od 12. do 19. septembra 1913. godine, a krajem aprila je bilo raspušteno Opšte radničko društvo Uzajamnost za Kranjsku (Rahten 2012: 186).

Tokom Prvog svetskog rata i promene vojne sreće na račun Antante, predstavnici jugoslovenskih naroda donose 20. jula 1917. godine na Krfu Krfsku deklaraciju, kompromisni dokument (Petranović 1988: 17), po kojem se zvanično odustaje od težnji za stvaranjem federalne države na račun stvaranje monarhije pod vođstvom dinastije Karađorđević. Ideja o federativnoj državi, izražena i u predavanju ovoga pisca, realizuje se tek tokom II svetskog rata, na drugom zasedanju AVNOJ-a. (Rastoder 2017: 100).

\section{Literatura}

Bojan BALKOVEC, 1995: Slovenska kronika XX. stoletja 1900-1941. Ljubljana: Nova revija.

Ivan CANKAR, 1966: Bela krizantema. Ljubljana: Mladinska knjiga.

Ana PAVLIČ, 2015: (Politični) imaginarij v delih Ivana Cankarja. magistrsko delo. Ljubljana: Fakulteta za družabne vede. Digitalna knjižnica fakultete za družabne vede. Veb. 30.5.2019.

Latinka PEROVIĆ, 2017: Jugoslavija u istorijskoj perspektivi. Iskustvo $s$ drugim narodima. Ur. Latinka Perović. Beograd: Helsinški odbor za ljudska prava u Srbiji. 202- 250.

Branko S. PETRANOVIĆ, 1988: Istorija Jugoslavije: 1918-1988. Beograd: Nolit.

Andrej RAHTEN, 2012: Jugoslovanska velika noč, Ljubljana: GV založba.

Šerbo RASTODER, 2017: Jugoslavija u istorijskoj perspektivi. Gubitak državnosti i njena obnova. Ur. Latinka Perović. Beograd: Helsinški odbor za ljudska prava u Srbiji. 82-114.

Josip VIDMAR. "Ivan Cankar (1876-1918). Naša sodobnost 4/6. preuzeto sa http://www.dlib.si/?URN=URN:NBN:SI:DOC-PHCXE4FY (30. 5. 2019)

Dan, 1913. II./467. Ljubljana. preuzeto sa http://www.dlib. si/?URN=URN:NBN:SI:doc-HOPOSRGP (4.6. 2019)

Slovenec, političen listza slovenskinarod (14.04.1913), letnik 41, številka 84, Ljubljana. preuzeto sa http://www.dlib.si/?URN=URN:NBN:SI:docXU6D6049 Veb:7.6.2019.

Slovenski narod, 1913. XLVI./84. Ljubljana. preuzeto sa http://www. dlib.si/?URN=URN:NBN:SI:doc-CFKCJ163 (7.6.2019)

Zarja, 1913. III./556. Ljubljana. preuzeto sa http://www.dlib. si/?URN=URN:NBN:SI:doc-NWYB21TD (5.6.2019) 


\title{
Aleksandar Trifunović
}

\section{CANKAR AND YUGOSLAVIA}

\begin{abstract}
Summary
The idea of the creation of common state of South Slavs was a notion that during 19th century and the 1st decade of 20th century was a guiding light of many politicians, but the idea was also supported by scientists and writers. Two fronts - monarchist and republican- of creating a country on the territory populated by Serbs, Croats and Slovenes as well as by other South Slavic nations were developing in completely different ways in order to eventually become a mixture of both, but unfotunately with no success. Slovene poet Ivan Cankar, who is remembered as one of the greatest Slovene writers, was also involved in politics. He presented his ideas in an essay entitled Slovenes and Yugoslavs, in which he expressed his thoughts about the future order of the country. The aim of this paper is to draw parallels between the ideas of the writer and events that actually occurred and to determine whether his ideas became reality after Kingdom of Serbs, Croats and Slovenes was created.
\end{abstract}

Key words: Ivan Cankar, writer, politician, Yugoslavia, kingdom, republic 